Revue interdisciplinaire sur la Grèce archaïque

$21 \mid 2018$

Varia

\title{
Avant-propos
}

"Civilizing Immigrants between Apotheosis and Damnation. A Theban

Overview"

\section{Paolo Cecconi}

\section{(2) OpenEdition \\ 1 Journals}

Electronic version

URL: https://journals.openedition.org/gaia/308

DOI: $10.4000 /$ gaia.308

ISSN: 2275-4776

\section{Publisher}

UGA Éditions/Université Grenoble Alpes

\section{Printed version}

ISBN: 978-2-37747-057-0

ISSN: 1287-3349

\section{Electronic reference}

Paolo Cecconi, "Avant-propos", Gaia [Online], 21 | 2018, Online since 01 November 2018, connection on 09 December 2021. URL: http://journals.openedition.org/gaia/308; DOI: https://doi.org/10.4000/gaia. 308

This text was automatically generated on 9 December 2021.

Gaia. Revue interdisciplinaire sur la Grèce archaïque 


\section{Avant-propos \\ "Civilizing Immigrants between Apotheosis and Damnation. A Theban Overview"}

\section{Paolo Cecconi}

\section{AUTHOR'S NOTE}

I would like to express my gratitude to all participants of the present collection of studies and to all peer-reviewers; to Gaia and their directors Malika Bastin-Hammou and Maria Paola Castiglioni for having accepted them. I am personally grateful to the friend and colleague Maria Paola Castiglioni for her competent suggestions and her constant help. Dear Maria Paola, I hope that we can have soon a coffee together.

To Angela and Aurelia

1 The study of the ancient world, of its culture, and of its societies is a research field in constant evolution. The archaeological explorations discover features of the ancient world, which were little-known or completely unknown so far; thus they open new fields of research, which require a revision of the acquired achievements. The recent discovery of about 250 clay tablets in Thebes' acropolis by V. Aravantinos at the end of 20th century has revealed unknown information about this ancient Greek city, whose mythological history played a fundamental role in the definition of the ancient thought, and rivalled Troy in the influence exerted upon the Western culture until today. ${ }^{1}$ Those tablets prove that Thebes was a key hub for transmission of goods, ideas and religious practices between East and West in the 13th century BC, a time when the major mythical tales of antiquity, like the Trojan War or the fall of the Argives and of Oedipus, arose. ${ }^{2}$ Those cultural exchanges might have influenced Thebes' mythological saga, and might explain us some mythological contradictions and some geographical and chronological narrative variations of its tales, whose historical origins are still not so clear. 
2 The studies of the historical function of mythological tales and of the nexus mythsociety have had a long tradition since the discovery of Troy by Heinrich Schliemann in 19th century and require a precise knowledge of the society behind the myths. ${ }^{3}$ V. Aravantinos has recently disclosed new data on Thebes, which enable us to read its history as a history of confrontation between two different worlds and two social groups: West and East, natives and immigrants; indeed Thebes' historical myths narrate its foundation in Boeotia by some immigrants from the East lead by a certain Cadmus. Then the newcomers brought civilization and mixed themselves with the native inhabitants of the colonized region; this union of different people has created the paradigm of a history of chaos, conflicts and civil disorders, which has found numerous uses and adaptations in the works of ancient authors from old epos to Attic drama, especially during the devastating crisis represented by the Peloponnesian War with the end of Athenian hegemony. ${ }^{4}$

3 The Greek literature offers numerous witnesses with both broad (epos and lyric) and local (Attic dramas) geographic and cultural points of view. Attic dramas are indeed the most complete literary sources of Theban myths, but, at the same time, reveal political uses of myths and transmit precise messages and programs to Athenian audience. ${ }^{5}$ In that context Cadmus' role as civilizing stranger was not deeply and enough investigated, but, thanks to the mentioned discoveries on Thebes' past and to a better knowledge of the early textual sources, an investigation of the mythological function of the civilizing stranger especially in the extraordinary framework of the Theban saga (Oedipodea, Thebaid, Epigoni, Alcmeonis), whose early sources survive only as summaries and fragments, is today possible. Moreover, Cadmus is the civilizing hero par excellence, not only for Greece (because he imported in Greece the alphabet according to Herodotus Hist., V, 58), but also for other regions like Thrace and Illyria. ${ }^{6}$ He is tightly connected with the city he founded, whose inhabitants were hence called "Cadmeians".

4 Religion and myths in Greece influenced both individual and collective lives, and defined both their political times and places. Religion and myths had historical functions and were hence so tightly bounded with social and public life, that they had constant interactions with political themes, ${ }^{7}$ and must hence be analysed by a mere Greek point of view, taking into account above all their historical and archaeological backgrounds. ${ }^{8}$ It should be also constantly noted that mythological sources are principally literary (poetical) texts, which add the fluidity of the mythological narration to poetical and textual variations and to the innovations of each single author (for each of them there is today a specific research field); for this reason archaeology is fundamental. ${ }^{9}$ Briefly, myths represented the narration of the past, ${ }^{10}$ and ancient authors considered them not as a sterile corpus but a living world. Indeed, after the fall of pre-classical civilizations, myths represent the memories of those old-times and explain their remains. ${ }^{11}$

5 Especially historical myths of urban communities like Thebes are strictly connected with social changes, define the places where they are set, ${ }^{12}$ and build cultural and national identities on the belief of the "autochthony". "Autochthony" is a central both political and mythological belief of ancient myths, not only of Theban ones; with "autochthony" ancient peoples meant that they were the first humans to inhabit their part of the earth and that they had lived there ever since. As a statement about the past, this belief served foremost to substantiate precise political interests in the present: when peoples declared themselves "autochthonous", this implied that a core 
of the population had remained the same over time; therefore its living members could assert their identity and uphold any interests based on this view of the past against the "newcomers". ${ }^{13}$ In this context the arrival of Cadmus opens interesting questions on his function as grounder of the Theban autochthony despite his foreign origins. ${ }^{14}$ Ideal counterparts of Cadmus are the Boeotian twins Amphion and Zethus, who gain the power on Thebes, erect its walls, and give it its current name. The historical tradition represented by Homeric epos considered Amphion and Zethus the founders of Thebes (even though Homers named Thebans as Cadmeians), and suggested thus at the same time both the presence of two different narrations of the past, a global one (Cadmus) and a local one (Amphion and Zethus), ${ }^{15}$ and of two ethnical and social groups (Thebans vs Cadmeians, natives vs immigrants). Of course Amphion and Zethus represent a negation of Cadmus' civilizing role.

The simple narration of Theban cycle evidences its interpretative questions and the numerous opportunities for innovative researches. Founder and first king of Thebes was the Phoenician Cadmus, who reached Boeotia and, following an oracle of Apollo, built his own city, originally called Cadmeia, and populated it with the Spartoi, the "sown men", who sprang up from the sowed teeth of the dragon of Ares he killed. When Cadmus died, his son Polydorus was still minor, and hence Pentheus, son of Cadmus' daughter Agaue and of one of the Spartoi, became king. He met a tragic end after falling foul of the young god Dionysus, son of his aunt Semele and of Zeus. Polydorus succeeded Pentheus but reigned for a short while. At his death, his father-inlaw Nycteus (son of Chthonius, one of the Spartoi) achieved the kingdom and acted as guardian for the young Labdacus, son of Polydorus. During the regency of Nycteus, Cadmeians started a war against Epopeus, the king of Sicyon (a city close to Corinth), who had abducted Nycteus' daughter, Antiope. Cadmeians were defeated and Nycteus himself died. His brother Lycus succeeded him as ruler. In the meantime, Labdacus became king and a war against Athens erupted; once again, Cadmeians were defeated. Labdacus survived the war, but, following the footsteps of Pentheus, he opposed the cult of Dionysus, and died leaving behind a young son, Laius. Lycus took control of the city again, this time as a usurper, and waged a victorious war against Sicyon to avenge his brother and his niece. Lycus and his wife Dirce imprisoned Antiope treating her cruelly, but she escaped and was reunited with Amphion and Zethus, hers and Zeus' sons, born in secret and raised by shepherds near Mount Cithaeron. Later Amphion and Zethus marched against Lycus and Dirce and killed them; they did not restore Laius to the throne but seized the power expelling him, expanded the city (renaming it Thebes) and built the seven gates. Amphion's wife Niobe attracted the wrath of the goddess Artemis, who killed all their children causing thus the suicide of Amphion. Zethus' son and only child died earlier, and he had died of a broken heart. Thus, the throne of Thebes was vacant and Thebans invited back Laius, who resided in the Peloponnesus under the protection of King Pelops, thereby restoring the original dynasty of Cadmus. Laius became king and married Jocasta, daughter of Menoeceus, son of Pentheus, but because of a Delphic oracle warning him not to have a son, who was fated to kill him, Laius exposed his offspring-who nevertheless survived, and grew up under the name of Oedipus. Later, Oedipus killed Laius and married Jocasta becoming king of Thebes and bringing up four children, including two sons, Polynices and Eteocles. When Tiresias revealed Oedipus' crimes-patricide, regicide and incest, no less-, he had to abdicate and was exiled by Polynices and Eteocles, who agreed that each should rule alternately for one year at a time. However, Eteocles reneged on the pact, and Polynices 
was banished from Thebes and fled to the court of King Adrastus of Argos to raise an army. In this war, Polynices and Eteocles killed each other. Hence Jocasta's brother, Creon, who before had governed Thebes after Laius' death and Oedipus' exile to Athens, became regent for Eteocles' son Laodamas and has had several clashes with Theseus, King of Athens. During one of Creon's regencies, Heracles was born in Thebes, lived with his parents under Creon's protection and married Megara, Creon's daughter. When Laodamas came of age, Creon resigned the rule to him. Laodamas was confronted with an attack led by Polynices' son Thersander, who succeeded and became king of Thebes. Laodamas died during the war. Thersander joined the Greek forces in the Trojan War, but died on the shores of Mysia. His son Tisamenus was too young at the time to lead the Theban contingent and participated to the war only in its final phases (Pausanias, Periegesis, IX). ${ }^{16}$

Some of the most significant critical features of Theban cycle are:

- Cadmus and his town: Cadmus is at the same time the civilizing hero par excellence (he imported Phoenician letters!) and an immigrant as other heroes like Pelops, Aegyptus and Danaus. ${ }^{17}$ Cadmus is tightly connected with the city he founded; its inhabitants were called indeed Cadmeians, and, as the same Theban Pindar stated, they named themselves so; even Aeschylus called the Thebans "Cadmeians" in Seven against Thebes. Cadmus generated the Spartoi, the ancestors of Theban aristocracy and the basis of Theban identity. ${ }^{18}$

- Amphion and Zethus: they constitute an interesting case of study of the relationships between Cadmeians and Boeotians, represented respectively by the couples Lycus/Dirce on the one hand and Amphion/Zethus on the other hand. The historical tradition represented by Homeric epos considers Amphion and Zethus the founders of Thebes, even though it named Thebans as Cadmeians, ${ }^{19}$ and proves thus the presence of two different narrations of the past, a Greek one (Cadmus), and a Boeotian one (Amphion and Zethus), and of two ethnical and social groups: Cadmeians vs Thebans, natives vs immigrants. Are Amphion and Zethus an attempt to remove the diversity of the Cadmeians and to rewrite Thebes' origins? The answer might be affirmative; indeed the brothers symbolize a different dynasty with local origin (Amphion and Zethus were grandsons of the Boeotian River Asopos, which guarantees their "Boeotian background" and their status). ${ }^{20}$ Their (second) foundation of Thebes creates a new idea of social and urban space, an urban duplicity and an antagonism between Thebes and the Cadmeia. This duplicity is not only the typical one between city and acropolis, but it is also ethnical and social: Thebans vs Cadmeians, natives vs strangers, West vs East. The archaeological excavations have evidenced the reliability of this duplicity, which is not only mythical but also historical. ${ }^{21}$

- Laius and Oedipus: Laius is an interesting Theban citizen, whose history lies in the shadows of his son Oedipus. During his exile in Peloponnese, Laius kidnapped and raped the young Chrysippus, son of his host Pelops. Because of that crime, Laius is the "inventor" of pederasty and homoerotic loves. He might be considered a civilizing stranger (like Cadmus), but his invention seems to have damned him: he and his descendants are cursed and damned by Pelops. ${ }^{22}$ Once returned to Thebes, Laius marries Jocasta, granddaughter of Pentheus, and becomes king of Thebes. With Laius, Cadmus' descendants come back to Thebes and join the indigenous (Jocasta). The ambiguous successive events of Oedipus and his sons seem to demonstrate that the union of two different social elements has ruined the city, as the Athenian tragedies suggest.

- The "Seven": they represent the climax of the Theban catastrophe and are the paradigm of war and civil war and the mythological model of the siege of Troy and of all conflicts among different factions. ${ }^{23}$ Indeed this clash is not only the clash between two Theban brothers, but 
between two cities, which could have had closer relationships than expected, if we assume that the Oriental Cadmus descended from the Argive Io (Euripides, Phoenissae, 239-248). In this case the clash between Oedipus' sons has to be read in the broader framework of immigrants' role and function in Theban myths, whose influence on modern culture is immense, because they constitute the model of a victorious defence of the homeland against the "Others". ${ }^{24}$

8 The investigation of the civilizing function of the immigrant Cadmus and of his relationships with the city he grounded is the aim of the present collection of essays, which collects contributions of historians, philologists and archaeologists on the following themes an on many others related topoi of "civilizing strangers" in the ancient literature:

- Rite of foundation, rite of colonization: Cadmus grounded a settlement of a different (superior?) culture on the Greek mainland (strangers and immigrants are also civilisers);

- One city, two foundations: co-existence of different myths or revisionism?

- Thebes and Thebans in literature: features of their presence;

- Amphion and Zethus against Cadmus: one region, two autochthonies;

- Reception of archaic myths in classical age: adaptations and re-readings.

The contributions to the present collection of studies consider carefully those scientific topics and offer new interesting causes for interdisciplinary reflections.

10 Karin Mackowiak takes into account the different interpretative readings of the "character Cadmus" by positivist, structuralist and linguistical points of view and suggests the need of new historical approaches, which link this hero and its saga with the social discourse of constructions of local elites. Cadmus is a "mean" to ensure Theban elites an illustrious ancestor.

11 Annamaria Peri investigates philologically and anthropologically the topic of “reciprocity and exchange" in Cadmus' myth. Cadmus brings gifts to Greece (i.e. the alphabet), but what has he received from Greece? Peri answers the question if the myth of Cadmus includes the idea of reciprocity and reveals the absence of one-ways in cultural exchanges.

12 Anna Miriam Biga analyses the "other" Theban myth of foundation by Amphion and Zethus. She suggests interesting answers to the question if this is a "second" and "different" myth or if Cadmus and the twins belonged to the same myth, modified afterwards.

13 Sabrina Mancuso sheds new light on reception of a special topic of Theban myth in the classical age: Zethus and his wife Aëdon. This myth is open to political interpretations (especially by Sophocles) because of its setting in Thrace and it can be therefore read as a critique of this region in a time of controversial relationships with Athens.

14 Alessandra Inglese offers an innovative archaeological analysis of a bronze epigraph from Herakles' sanctuary in Thebes of the 5th century $B C$, which reveals new features of the mythological and social uses of the characterisation of Herkles.

15 Emiliano Cruccas outlines some features of the daemonic figure of "Herakles Daktylos", which connects together both Boeotia and Phoenicia: indeed Herakles Daktylos is close to Semitic gods like Melqart and Ptah and reveals apotropaic powers, which recur in female amulets of both Hellenistic and Roman eras. 
André Hurst delivers an in-depth analysis of Pindar's strategies to vindicate the bad image of his city after the Persian wars. Pindar seems to be preoccupied because of Thebes' reputation and tries to glorify Thebes by celebrating any victory won by a Theban athlete.

Paola Schirripa focuses hers attention on Labdacides' saga in Euripides' Phoenician Women, which seems to treat Theban myths in an extremely chaotic and confuse way, in order to discuss their choral function as anthology of myth in one piece. Euripides combines selected narrative features of the Theban saga with continuous allusions to current wartime.

18 Federica Cordano delves with the topic of burials of Pythagorean philosophers taking into account the one of Lysis of Taras, who died in Thebes. Lysis' burial is contextualised in the small framework of the few information about Pythagorean burials we have.

19 This collection of essays is the result of a tight collaboration between classical philology, archaeology, history and religious studies; it provides the necessary tools to develop the multidisciplinary analysis of the presence of immigrants and their relationships with natives in Theban myths and intends to address this challenge by drawing on the theory that myths were religious expressions of a society, and thus by "seeing ancient Greece with Greek eyes". ${ }^{25}$

20 Aim of the present collection of essays is thus to open several new opportunities of research, and to shed new light on still hidden features of the ancient world. Indeed, only if we know "who we were", we can assert "who we are" and, thus, we can try to imagine "who we will be". ${ }^{26}$

\section{BIBLIOGRAPHY}

ALBA Richard \& FONER Nancy, Strangers No More: Immigration and the Challenges of Integration in North America and Western Europe, Princeton, Princeton University Press, 2015.

AMBÜHL Annemarie, Krieg und Bürgerkrieg bei Lucan und in der griechischen Literatur. Studien zur Rezeption der attischen Tragödie und der hellenistischen Dichtung im Bellum Civile, Berlin-Boston, De Gruyter, 2015.

ARAVANTINOS Vassilis (ed.), Thèbes. Fouilles de la Cadmèe (4 vol.), Roma, Istituti editoriali e poligrafici internazionali, 2006.

ASSMANN Jan, Das kulturelle Gedächtnis: Schrift, Erinnerung und politische Identität in frühen Hochkulturen, München, Beck, 1992.

BERMAN Daniel, Myth Literature and the Creation of the Topography of Thebes, Cambridge, Cambridge University Press, 2015.

BERNARDINI Paola (ed.), Presenza e funzione della città di Tebe nella cultura greca, Pisa-Roma, Istituti editoriali e poligrafici internazionali, 2000. 
BLOK J. H., "Gentrifying Genealogy: On the Genesis of the Athenian Autochthony Myth", in U. Dill \& C. Walde, Antike Mythen. Medien Transformationen und Konstruktionen, Berlin-New York, De Gruyter, 2009.

BREMMER Jan, “Myth As Propaganda: Athens and Sparta”, ZPE, 117, 1997, pp. 9-17.

BURKERT Walter, "Seven against Thebes: An Oral Tradition between Babylonian Magic and Greek Literature”, in C. Brillante, M. Cantilena \& C. O. Pavese, I poemi epici rapsodici non omerici e la tradizione orale, Padova, Antenore, 1981, pp. 29-51.

CASTIGLIONI Maria Paola, "Sulle tracce di Cadmo metallurgo in Tracia", in T. Alfieri Tonini, G. Bagnasco, F. Cordano (eds), Culti e miti greci in aree periferiche, Trento, Tangram, 2012, pp. 205218.

CASTIGLIONI Maria Paola, Cadmos-serpent en Illyrie. Itinéraire d'un héros civilisateur, Pisa, Pisa University Press, 2010.

CINGANO Ettore, “Oedipodea”, in M. Fantuzzi \& C. Tsagalis, The Greek Epic Cycle and Its Ancient Reception. A Companion, Cambridge, Cambridge University Press, 2015a, pp. 213-225.

CINGANO Ettore, "Epigonoi", in M. Fantuzzi \& C. Tsagalis, The Greek Epic Cycle and Its Ancient Reception. A Companion, Cambridge, Cambridge University Press, 2015b, pp. 244-260.

DAVIES Malcom, The Theban Epics, Cambridge (Mass.), Center for Hellenic Studies, 2014.

KIRK Geoffrey, Myth. Its Meaning and Function in Ancient and Other Cultures, Cambridge, Cambridge University Press, 1970.

FINGLASS Patrick, Pindar. Pythian Eleven, Cambridge, Cambridge University Press, 2007.

FINLEY Moses, The World of Odysseus, New York, The Viking Press, 1954.

FÖLLINGER Sabine, Genosdependenzen. Studien zur Arbeit am Mythos bei Aischylos, Göttingen, Vandenhoeck \& Ruprecht, 2003.

GÖDDE Susanne, "Fremde Nähe. Zur mythologischen Differenz des Dionysos”, in R. Schlesier, A Different God? Dionysos and Ancient Polytheism, Berlin-Boston, De Gruyter, 2011, pp. 85-104.

HARD Robin \& ROSE Herbert Jennings, “The Mythical History of Thebes”, in R. Hard, The Routledge Handbook of Greek Mythology, London, Psychology Press, 2004, pp. 294-335.

HURST André, "Bâtir les murailles de Thèbes", in P. Bernardini, Presenza e funzione della città di Tebe nella cultura greca, Pisa-Roma, Istituti editoriali e poligrafici internazionali, 2000, pp. 63-84. IRIGOIN Jean, Bacchylide : Dithyrambes, épinicies, fragments, Paris, Les Belles Lettres, 1993.

KÄMMERER Thomas \& METZLER Kai, Das babylonische Weltschöpfungsepos Enûma elîsch, Münster, Ugarit-Verlag, 2012.

KÜHR Angela, Als Kadmos nach Boiotien kam: Polis und Ethnos im Spiegel thebanischer Gründungsmythen, Stuttgart, Franz Steiner Verlag, 2006.

MARKANTONATOS Antonis \& ZIMMERMANN Bernard, Crisis on Stage: Tragedy and Comedy in Late Fifth-Century Athens, Berlin-Boston, De Gruyter, 2011.

MASTRONARDE Donald, Euripides' Phoenissae, Cambridge, University Press, 1994.

MÜLLER Dietram, Topographisch-geographisches Bildlexikon zum Geschichtswerk Thukydides, Wiesbaden, Chelmos, 2013.

OLIVIERI Oretta, Miti e culti tebani nella poesia di Pindaro, Pisa, Serra, 2011. 
OLIVIERI Oretta, “Asopo, fiume interregionale: le tradizioni locali nell'epica di Eumelo e nella poesia lirica arcaica”, in P. Bernardini (ed.), L'epos minore, le tradizioni locali e la poesia arcaica, PisaRome, Fabrizio Serra, 2007, pp. 15-24.

OTTO Walter Friedrich, Die Götter Griechenlands. Das Bild des göttlichen im Spiegel des griechischen Geistes, Bonn, Cohen, 1929.

TZANETOU Angeliki, City of Suppliants: Tragedy and the Athenian Empire, Austin, University of Texas Press, 2012.

\section{NOTES}

1. Davies (2014, 4), Aravantinos (2006, II, 319-325), Berman $(2015,41)$, Bernardini $(2000,7)$.

2. Aravantinos (2006, I, 27-59; II, 12-16; II, 357-358).

3. Assmann (1992), Kirk (1970, 262).

4. Tzanetou (2011, 104-105). His study investigates the relationships between tragedy and Athenian hegemony. Employing careful historical readings of few selected texts, Tzanetou comprises several connected arguments, evidencing how the portrayals of Athens are strongly shaped by contemporary political affairs (Athens' intense rivalry with Sparta). Additionally he traces a historical development in Athenian hegemonic ideology as the Athenian empire developed and as idealized justifications of Athenian power became harder to sustain because of the changing war occurrences. Concerning Oedipus at Colonus, for instance, Tzanetou argues that this play represents a crisis in Athenian ideology, which corresponds to a decline of Athens' hegemony in the later Peloponnesian War.

5. Markantonatos \& Zimmermann (2011, V-XI), Bremmer (1997, 9-12).

6. Castiglioni (2012, 205-210; 2010, 192-193).

7. Bremmer (1997, 9-12).

8. Finley (1954), Otto (1929). The study of myths as primary form of expression of ancient society reveals a rich and variegated tradition with historical and religious analysis of myth e.g. Gödde (2011, 85-104) and Föllinger (2003) and with philological studies of the literary sources of the myth, e.g. Finglass (2007) and Irigoin (1993).

9. Vian $(1963,10-12)$.

10. Kirk $(1970,40)$.

11. Berman $(2015,47)$.

12. Kühr $(2006,132)$.

13. Blok (2009, 251-258).

14. Olivieri (2011, 24-27).

15. Olivieri $(2011,40)$.

16. Hard \& Rose $(2004,294)$.

17. Castiglioni (2010, 190-195).

18. Olivieri $(2007,24)$, Kühr $(2006,132)$.

19. Hurst $(2000,63-70)$.

20. Olivieri $(2007,24)$.

21. Müller (2013, 227-228).

22. Cingano (2015a, 213-225), Mastronarde (1994).

23. Cingano (2015b, 244-260), Berman (2015, 47-48), Kämmerer \& Metzler (2012), Burkert (1981, 29-51).

24. Ambühl (2015).

25. Otto (1929).

26. Alba \& Foner (2015). 


\section{AUTHOR}

\section{PAOLO CECCONI}

Kulturbetrieb Chemnitz - Stadtarchiv.

Après avoir obtenu un master en sciences de l'Antiquité à l'université de Pise, un doctorat en philologie grecque et latine à l'université de Florence et un diplôme de paléographie grecque et de paléographie et archivistique à la Scuola Vaticana di Paleografia Diplomatica e Archivistica, Paolo Cecconi est chercheur à l'Institut de philologie classique de l'université de Würzburg. Depuis 2017 il est directeur des Archives de la ville de Chemnitz. Il s'intéresse à l'histoire de Chemnitz et de la Saxe, à l'histoire industrielle, à la littérature chrétienne et à l'étude des relations entre mythe et politique dans l'Antiquité. 